\title{
Международная конференция «ХХ Славистические чтения памяти проф. П. А. Дмитриева и проф. Г. И. Сафронова», 12 сентября 2018 года, Санкт-Петербург, Россия
}

Свою историю кафедра славянской филологии - одна из старейших кафедр СПбГУ - ведёт с 1835 года, когда в Петербургском университете была основана «кафедра по истории и литературе славянских наречий». За долгое время кафедру возглавляли такие учёные, как П. И. Прейс (1835-1846), И. И. Срезневский (18471880), В. Ягич (1880-1886), В. И. Ламанский (1886-1888), А. И. Соболевский (18881908), А. А. Шахматов (1908-1920), Н. С. Державин (1935-1941, 1944-1955), Э. А. Якубинская-Лемберг (1948-1961), Б. А. Ларин (1961-1964). П. А. Дмитриев (1964-1998), М. Ю. Котова (1998-2017).

Петр Андреевич Дмитриев - доктор филологических наук, профессор ЛГУ/ СПбГУ, член Академии гуманитарных наук, выдающийся учёный-славист, возглавлял кафедру славянской филологии более 30 лет — с 1964 по 1998 гг. — был заместителем декана по учебной работе. Основными направлениями его исследований были проблемы сербохорватского и сравнительного славянского синтаксиса, история славянской филологии, русско-югославянские литературные и научные связи. Профессор П. А. Дмитриев стал инициатором изучения славянских языков на отделениях русской, украинской, белорусской филологии в 19 институтах страны.

Герман Иванович Сафронов — кандидат филологических наук, профессор ЛГУ/СПбГУ, учёный-сербокроатист, автор большого количества трудов. Их с Петром Андреевичем объединяло не только общее дело, но и крепкая дружба, которую они сохраняли на протяжении долгих лет.

Данная конференция с 1999 года ежегодно проводится кафедрой славянской филологии Санкт-Петербургского государственного университета в день рождения П. А. Дмитриева и день памяти Г. И. Сафронова. За первые 10 лет на конференции слависты из десятков научных центров разных городов России и зарубежья выступили с несколькими сотнями докладов на всех славянских языках. Темы выступлений касались различных областей славистической науки: истории славяноведения, методики преподавания, перевода, грамматики, лексики, фразеологии и паремиологии и др. По материалам конференций ежегодно издавались сборники докладов ${ }^{1}$.

Двадцатая конференция стала международной: было заявлено и прозвучало более 40 докладов из разных стран. Открытие состоялось 12 сентября 2018 года в кинозале СПбГУ. С приветственным словом к участникам конференции высту-

1 См. библиографию. 
пил заместитель декана филологического факультета профессор С. Т. Нефёдов. Он отметил открытость кафедры славянской филологии СПбГУ для международного сотрудничества, сказал, что данная конференция является нужной и востребованной в научном сообществе. Также профессор С. Т. Нефёдов подчеркнул авторитетность петербургских славистов в филологическом сообществе и поблагодарил их за продвижение изучения славянских языков и литератур.

Тематика пленарных докладов была разнообразной. В первом совместном докладе профессора М. Ю. Котовой и доцента О. В. Раины (и.о. заведующей кафедры славянской филологии) О. В. Раина рассказала о работе кафедры за двадцатилетний период, об истории и традициях. За этот период было защищено более 20 кандидатских и докторских диссертаций, выпущено более 1500 статей, более 20 учебных пособий, несколько монографий. В настоящее время кафедра проводит подготовку бакалавров, магистров, аспирантов в нескольких направлениях: лингвистика, литературоведение, теория и практика перевода, славяно-германская компаративистика, изучение культурных взаимосвязей. Студенты изучают 11 славянских языков (болгарский, польский, чешский, словацкий, украинский и другие). О. В. Раина сообщила, что преподаватели кафедры славянской филологии СПбГУ поддерживают связи с различными университетами, в том числе зарубежными, ежегодно принимают участие в международной конференции филологов СПбГУ.

В докладе профессора Мордовского государственного университета А. Ю. Масловой «Особенности репрезентации фразеосемантического поля 'речевая деятельность’» были выявлены межъязыковые сходства и различия в русском, болгарском и сербском языках. В анализируемых фразеологических единицах было представлено речевое поведение, в рамках которого рассматривались такие аспекты, как собственно поведение говорящего, его отношение к собеседнику, речевое воздействие, а также молчание участников коммуникации.

Профессор СПбГУ В. М. Мокиенко представил доклад «“Пословицы” Вука Караджича в современном контексте», в котором подчеркнул актуальность сборника, составленного около 200 лет назад. Материалы, собранные В. Караджичем, используются в настоящее время при создании паремиологических минимумов и пособий, в том числе преподавателями СПбГУ. Кроме того, его труд имеет большое значение для учёных-диахронистов, что делает его востребованным в наше время.

13 сентября 2018 года состоялось пять заседаний в секциях «Славянские литературы», «История славистики», «Современные славянские языки», «История и диалектология славянских языков», «Славянская лингводидактика». Секция «Славянские литературы» явилась самой масштабной и провела три заседания, секция «Современные славянские языки» состояла из двух заседаний, секции «История славистики», «История и диалектология славянских языков», «Славянская лингводидактика» - по одному заседанию.

Доцент 3. К. Шанова отметила постоянство секции «История славистики», которая ведёт свою деятельность на различных конференциях, проходящих также в рамках других конференций. На настоящей конференции в данной секции были представлены четыре доклада. Кандидат филолологических наук Д. Дракулич-Прийма (Библиотека РАН) рассказала о находящейся в библиотеке Академии наук коллекции книг из личного собрания Вука Караджича и о проходящей там выставке. В докладе доцента Н. А. Бондаренко (Институт языков и культур им. Л. Н. Толстого) прозвучал рассказ о «Славянском вестнике» А. А. Хованского и его 
значении для славистических наук. Выпускницы кафедры кандидаты филолологических наук К. Б. Егорова (ИРЛИ РАН, СПб) и Н. А. Родионова (СПбГУ) выступили с докладами о роли русской эмиграции в культурной жизни подкарпатской Руси и о слависте докторе филологических наук О. М. Малевиче, выпускнике кафедры, который работал в области художественного перевода с чешского языка.

В рамках секции славянских литератур были представлены самые разнообразные доклады от фольклора до постмодернизма, обсуждались различные подходы к изучению литературы, различные литературные направления от неоязычества до гибридных литературных форм. Доцент кафедры Т. Е. Аникина исследовала тенденции в современных славянских литературах. Доктор филологических наук А. Б. Базилевский (ИМЛИ РАН) рассказал о славянской библиотеке издательства «Вахазар», главной задачей которого является распространение литературных произведений, не имеющих популярности среди известных издательств, но представляющих собой ценность для читателя. На двух заседаниях секции прозвучали выступления о поэтах и писателях Сербии (кандидат филологических наук Е. В. Сартаков, МГУ им. Ломоносова), Хорватии (доктор филологии С. Поробич, Германия, Гамбург; кандидат филологических наук М. Н. Дробышева, ЛГУ им. Пушкина), Черногории (доктор филологических наук А. Г. Шешкен, МГУ им. Ломоносова), Словении (доктор филологических наук Н. Н. Старикова, Институт славяноведения РАН; профессор М. Штухец, Словения, Марибор), Болгарии (доктор филол. Наук М. Огойска, Болгария, София), Чехии (доцент А. Ю.Колянов, ЛЭТИ) и Польши (доцент О. В. Гусева, СПбГУ).

На секции современных славянских языков обсуждались актуальные лингвистические проблемы болгаристики, сербистики, полонистики, украинистики и других языков. Профессор Н. Е. Ананьева проанализировала языковые средства выражения понятия «пустота» и его дериваты, привела польские и русские параллели. Профессор Е. Ю. Иванова (СПбГУ) представила совместный доклад с кандидатом филологических наук В. А. Лазаревой (Италия, Салерно) о тавтологиях типа «Х сор Х» в болгарском языке в свете корпусных данных. В своём докладе кандидат филологических наук Н. Г. Самедова (Азербайджан, Баку) предложила особую схему глаголов движения, которая выявила лучшие достижения русских исследователей. Доцент О. Н. Шапкина (МГУ имени М. В. Ломоносова) проанализировала польские метафорические квантификаторы типа «море цветов» и «поток упрёков». Представленные кандидатом филологическом наук А. Пенчевой (Болгария, София) метафорические модели отражают феномен коррупции в текстах СМИ и связаны с болезнями, войной, растениями. Выступление доктора филологических наук Д. Раткович (Сербия, Белград) было посвящено сравнительному анализу семантического спектра лексемы погода в русском, сербском и польском языках, что выявило специфические положения слова погода в лексических системах данных языков. Сотрудник кафедры славянской филологии МГУ им. Ломоносова, кандидат филологических наук М. Л. Кулешова сопоставила наречия низкой степени (malo, premalo, nekoliko) в современном словенском языке на основе нескольких дифференциальных признаков. В докладе доктора Д. Пытель-Пандей (Польша, Вроцлав) были представлены языковые и неязыковые факторы, определяющие успешность коммуникации в современном польском языке. Внимание докладчика было направлено на польские нормы вежливого языкового поведения, новые веяния в поведении поляков и их влияние на коммуникацию. Доклад кандидата филологических наук А. В. Савченко 
(Тайвань, Тайбэй) и кандидата филологических наук М. С. Хмелевского (СПбГУ) о языковом портрете Киева вызвал бурное обсуждение слушателей. Языковая ситуация в Киеве представляет собой феномен современного билингвизма, для которого авторы предложили использовать термин «городское многоголосие». Основной задачей исследования кандидата филологических наук А. Г. Мосинец (СПбГУ) «Русские переводческие соответствия болгарского дубитатива» явилось установление болгарских и русских соответствий на основе корпусов параллельных текстов.

Проблемы преподавания славянских языков обсуждались на секции «Славянская лингводидактика», где были представлены четыре доклада. Доцент О. О. Лешкова (МГУ им. М. В. Ломоносова) говорила о проблеме современного учебника по польскому языку для русскоговорящих, так как большинство нынешних учебников являются морально устаревшими, и нуждаются в переработке. Два исследования были посвящены организации преподавания славянских языков. Доклад профессора Н. Пирих-Светиной (Словения, Любляна) представлял особенности преподавания словенского языка в Словении, а выступление М. Мамаевой (Германия, Гамбург) - проблемы преподавания славянских языков в неславянской стране. Доцент СПбГУ А. В. Бабанов высказал идею объединения методистов разных стран, поскольку проблемы преподавания славянских языков зачастую являются весьма схожими.

Секция истории и диалектологии славянских языков началась с доклада доцента О. И. Трофимкиной (СПбГУ) о библейских выражениях «юдоль плачевная» и «земля обетованная» в русском и сербском литературных языках. Доклады по диалектологии были достаточно разнообразными. О родопских говорах и их значении в современном мире рассказала кандидат филологических наук М. Н. Белова (МГУ им. М. В. Ломоносова). Выпускница кафедры славянской филологии СПбГУ, доцент В. И. Ушинскене (Литва, Вильнюс) представила доклад на стыке истории языка и диалектологии о лексических архаизмах в польских говорах на территории Литвы, где наблюдается большое влияние русского языка. Доцент Е. И. Якушкина (МГУ им. М. В. Ломоносова) не только рассказала о лексической дифференциации хорватских говоров, но и продемонстрировала схемы и атлас говоров. Завершал секцию доклад доцента И. В. Кузьмина (ННГУ им. Н. И. Лобачевского, Нижний Новгород) «Характеристика человека в русской и польской фразеосистемах (на примере ФЕ с зоокомпонентом)», представляющий характеристику человека и мира сквозь призму зоофразеологии.

На всех секциях проходили дискуссии о важных проблемах славяноведения. Большое количество докладчиков из различных городов России и зарубежных университетов подтверждает значимость кафедры славянской филологии СПбГУ как важного центра изучения славистики, в развитие которой внесли весомый вклад профессора П. А. Дмитриев и Г. И. Сафронов.

\section{Библиография}

Slavisticheskie chteniia pamiati prof. P. A. Dmitrieva i prof. G. I. Safronova: Materialy mezhdunarodnoi nauchnoi konferentsii 12-14 sentiabria 1999 g., Sankt-Peterburg: Filologicheskii fakul'tet SPbGU, 1999. 
Slavisticheskie chteniia pamiati prof. P. A. Dmitrieva i prof. G. I. Safronova: Materialy mezhdunarodnoi nauchnoi konferentsii 12-14 sentiabria 2000 g. / Otv. red. M. Iu. Kotova, Sankt-Peterburg: Filologicheskii fakul'tet SPbGU, 2001.

Slavisticheskie chteniia pamiati professora P. A. Dmitrieva i professora G. I. Safronova: Materialy mezhdunarodnoi nauchnoi konferentsii 12-14 sentiabria 2001 g. / Otv. red. M. Iu.Kotova, Sankt-Peterburg: Filologicheskii fakul'tet SPbGU, 2002.

Slavisticheskie chteniia pamiati professora P. A. Dmitrieva i professora G. I. Safronova: Materialy mezhdunarodnoi nauchnoi konferentsii 12-14 sentiabria 2002 g. / Otv. red. M. Iu. Kotova, Sankt-Peterburg: Filologicheskii fakul'tet SPbGU, 2003.

Slavisticheskie chteniia pamiati professora P. A. Dmitrieva i professora G. I. Safronova: Materialy mezhdunarodnoi nauchnoi konferentsii 11-13 sentiabria 2003 g. / Otv. red. E. Iu. Ivanova, Sankt-Peterburg: Filologicheskii fakul'tet SPbGU, 2004.

Slavisticheskie chteniia pamiati professora P. A. Dmitrieva i professora G. I. Safronova: Materialy mezhdunarodnoi nauchnoi konferentsii 9-11 sentiabria 2004 g. / Otv. red.y E. Iu. Ivanova, M. Iu. Kotova, Sankt-Peterburg: Filologicheskii fakul'tet SPbGU, 2005.

Slavisticheskie chteniia pamiati prof. P. A. Dmitrieva i prof. G. I. Safronova. Slavianskaia filologiia v sovremennoi sisteme universitetskogo obrazovaniia. Materialy mezhdunarodnoi nauchnoi konferentsii 12-13 sentiabria 2006 goda / Otv. red. M. Iu. Kotova, Sankt-Peterburg: Izdatel'skii dom Sankt-Peterburgskogo universiteta, 2007.

Slavisticheskie chteniia pamiati prof. P. A. Dmitrieva i prof. G. I. Safronova: Materialy mezhvuzovskoi nauchnoi konferentsii 12-13 sentiabria 2007 goda / Otv. red. M. I. Kotova, Sankt-Peterburg: Fakul'tet filologii i iskusstv SPbGU, 2008.

Slavisticheskie chteniia pamiati professora P. A. Dmitrieva i prof. G. I. Safronova: Materialy mezhvuzovskoi nauchnoi konferentsii 12-13 sentiabria 2008 goda / Otv. red. M. Iu. Kotova, Sankt-Peterburg: Fakul'tet filologii i iskusstv SPbGU, 2010.

Aliona Shestakova-Stukun

ORCID: 0000-0002-0674-1374

Petersburski Uniwersytet Państwowy

\section{2th Interdisciplinary Colloquium on Proverbs, 4-11 November 2018, Tavira, Portugal}

Tavira is a picturesque coastal fishing and holiday city in the south of Portugal; and it possesses the proud title of the world capital of proverbs. Fully supported by the local authorities, the city hosted this year the 12th Interdisciplinary Colloquium on Proverbs of the International Association of Paremiology (AIP-IAP),${ }^{1}$ welcoming participants from 28 countries all around the globe, ${ }^{2}$ including first-time attendees from New Zealand and Turkey.

1 http://www.colloquium-proverbs.org/icp/en/ (accessed: 7.12.2018).

2 Participating countries: Angola, Argentina, Belgium, Brazil, Croatia, Czech Republic, Estonia, Finland, Germany, Greece, Hungary, India, Iran, Ireland, Morocco, New Zealand, Nigeria, Norway, Poland, Portugal, Romania, Russia, South Africa, Spain, The Netherlands, Turkey, UK, USA. 